\title{
Liquidity, leverage, and cash holding: Evidence from In- donesia listed real estate firms
}

\author{
Zunairoh ${ }^{1}$, Fatkhurrohman ${ }^{2 *}$ \\ ${ }^{1}$ Airlangga University, Surabaya, Indonesia \\ ${ }^{2}$ Gadjah Mada University, Yogyakarta, Indonesia
}

\section{Keywords \\ Cash holding \\ Liquidity \\ Leverage \\ Dividend payment \\ Firm size}

Received: 7 February 2019

Accepted: 12 March 2019

Published: 24 April 2019

\begin{abstract}
This study aims to examine the effect of liquidity and leverage with variable control dividend payment and company size on cash holding in property \& real estate companies in Indonesia during the period 2012-2016. The research method used is multiple linear regression analysis. Based on the analysis results, it can be concluded that the variables liquidity, leverage, and dividend payment have a positive effect on cash holding, while the firm size has a negative effect on cash holding. The purpose of this paper is to find empirical evidence to analyze the effect of liquidity and leverage with dividend payment control variables and firm size on cash holding. This study uses a quantitative approach, namely by recording and analyzing the research data in an exact manner using statistical calculations. Based on the results of data analysis that refers to research objectives, hypotheses, and analysis models, it can be concluded that in property and real estate companies, liquidity variables have a significant positive effect, variable size has a significant negative effect, and leverage and dividend payment have no significant positive effect on cash holding. This research is relevant in the current times as the property and real estate industry can be rampant lately due to the tax amnesty turmoil that has made this sector more crowded. Naturally, it requires a place to increase with the increasing population. More properties in Indonesia are mentioned by the growth of the tourism and business sector. Cash management is needed as a consideration in investment decisions.
\end{abstract}

(C) 2019 The Author(s). Published by TAF Publishing.

\section{INTRODUCTION}

Cash is the company's most liquid assets and the life of every business. The dilemma faced by companies is how many companies need to hold cash holding because cash is a nonlearning asset while assets can be used for other investments that produce. Cash also plays an important role in this modern world. According to (Al-Najjar \& Clark, 2017; Hosban, 2016), companies may hold cash to meet contingencies in the future but companies may not invest in profitable projects. Holding too much money also has a lower return on investment than real assets. A free cash flow argument that explains managerial opportunism that holding cash causes accumulation of money that is detrimental to shareholders because of the rate of return which is the right of shareholders below what is supposed to (Jinkar Mali, 2011; Koroleva, Mierina, \& Karklina, 2017).
The economic crisis that occurred in 1997-1998 and 2008 was further aggravated because many companies did not maintain liquidity. One example of a sector affected by the financial crisis that caused this sector to stop suddenly was the property and real estate sector because this sector was very dependent on large bank debt. The financial crisis that has occurred has largely changed the views of large companies regarding the importance of maintaining liquidity and minimizing liquidity risk by maintaining cash interest rates. According to Ferreira and Vilela (2004), cash can reduce the possibility of financial difficulties. In property \& real estate companies, most of the assets held in the usual form are fixed assets that are difficult to convert into cash immediately. According to Al-Najjar and Clark (2017), Ozkan and Ozkan (2004), companies with more liquid assets can easily convert these assets into cash so that the company

\footnotetext{
*corresponding author: Fatkhurrohman

†email: fatkhurhero@gmail.com
} 
has lower cash. This is inversely proportional to the assets of illiquid property companies that need more cash to be maintained and most of the funding uses long-term debt. According to Hunjra, Shabbir, and Niazi (2012), the greater the company involved in debt, the greater the need to hold cash that must be maintained to avoid bankruptcy.

The property and real estate industry can be called rampant lately because the turmoil of tax amnesty has made the sector more crowded. Naturally needing a place to live will continue to increase as the population increases. More properties in Indonesia are mentioned by the growth of the tourism and business sectors (Kompas, 2008). The high demand is still far more than the property supply by property developers which causes prices to continue to increase. Based on the BI survey, the relative stock of residential stock compared to the population census has caused a significant pile of property demand and supply (Kompas, 2008). In addition, Indonesia still lacks housing supply, supplies housing deficits so the property market is still very large. Thus, it can be concluded that the property industry has a high level of competitiveness and promising prospects going forward (Kompas, 2008).

Various studies on the factors that determine cash holding have been carried out by researchers with various variables. Al-Najjar and Clark (2017), using variables such as leverage, dividend payments, profitability, liquidity, and size in influencing companies holding cash. Based on what has been described above, the authors are interested in discussing the effect of liquidity and leverage on cash holding. The purpose of this paper is to find empirical evidence to analyze the effect of liquidity and leverage with control variables on dividend payments and the size of firms holding cash. In particular, we will handle questions that are a major concern among money-earners in particular: whether leverage, liquidity, dividend payments, and the size of companies holding cash on property \& real estate companies. This research is very interesting because the property and real estate industry can be called rampant, due to the tax amnesty that has made this sector more crowded. Naturally it requires a place to increase with increasing population. More properties in Indonesia are mentioned by the growth of tourism and business sectors (Kompas, 2008). Therefore, cash management is needed as a consideration in investment decisions. The remainder of this paper is organized as follows: part two provides a theoretical and empirical framework from previous studies. The third part describes the research methodology used in this study. The next section reports and discusses findings for research. Last part concludes the study by summarizing the findings and dis- cussing the contribution of research to the literature, limitations and suggestions for further research.

\section{LITERATURE REVIEW Trade-off Theory}

The trade-off theory states that optimal liquidity is a tradeoff between the costs and benefits of holding cash. The benefits of holding cash including cash reduce financial difficulties because cash can be a security reserve for something that cannot be predicted by the company, allowing companies to achieve optimal investment policies when experiencing financial difficulties, and minimizing the costs of increasing external funds. This theory also argues that the motive for holding a cash company is the motive of transaction costs and careful motives. This theory shows that companies have cash because collecting funds in the capital market is more expensive than holding back money, for example because external financing involves fixed costs (Ozkan \& Ozkan, 2004; Willy, 2017). This cost component shows that there is an optimal amount of cash and causes the company to hold money as a buffer.

\section{Pecking Order Theory}

Pecking order theory says that with asymmetric information, companies prefer to finance upfront with internal cash, second with low risk debt and finally with equity (Alshannag, Basah, \& Khairi, 2017; Myers \& Majluf, 1984). This theory also explains that companies with high levels of profitability have low debt because of the abundant internal funding sources.

\section{Agency Theory}

This theory explains that the level of cash ownership raises concerns when managers do not act in the interests of shareholders. Managers have an incentive to save large amounts of money in order to have more flexibility to achieve their own goals while avoiding risks. In addition, managers also prefer to hold large cash reserves to help overcome unexpected difficulties, for example in periods when access to capital markets is expensive. Investment in cash can have a detrimental impact on company value, which then harms the interests of shareholders (Antara, Musa, \& Hassan, 2016; Jensen, 1986). Agency theory holds two hypotheses, namely.

\section{Free cash flow hypothesis}

Cash holding is seen as free cash flow because cash can be used by managers to serve their own interests at the expense of shareholders, thus exacerbating conflicts of interest between the two parties. 


\section{The risk-reduction hypothesis}

Cash holding is considered a risk-free investment. Managers avoid risk will increase cash holding to reduce the company's risk exposure.

In the cash holding theory, profits hold cash for companies according to Opler, Pinkowitz, Stulz, and Williamson (1999):

a. The company is able to save transaction costs and does not need to liquidate assets if the company requires cash.

b. If the source of financing outside of cash is difficult to obtain or very expensive.

c. Having cash is very useful as a source of financing, especially when there is a credit crunch.

John Maynard Keynes mentions three motives, namely, to hold cash, namely the motive of the transaction, the motive of speculation, and the motive just in case. Revealed the company's motives for holding cash as follows:

\section{The Transaction Motive}

This motive explains that the main advantage of holding cash is that the company can minimize transaction costs. In a sense, companies will hold large amounts of cash when the transaction costs are high for converting non-cash assets to cash. Meanwhile, companies will hold less cash when the opportunity cost of cash is higher, there is a tendency for companies to use their cash to finance more profitable investment opportunities.

\section{The Precautionary Motive}

Based on this theory, companies hold large amounts of cash with the aim of being able to deal with adverse shocks when access to capital markets is expensive. Thus, companies with better investment opportunities will hold larger amounts of cash so that they can still finance their investment needs even though economic shocks and financial distress are taking place. Companies with cash flows that are uncertain and have difficulties in obtaining external capital will hold more cash in cash (Opler et al., 1999; Srisangkaew, 2017). For companies with easy access to obtain external capital they may not have an effect on the size of the cash balance in their balance sheets, but for companies that have limited access to external capital the size of the cash balance on their balance sheet greatly affects the survival of the company. If the company only have a small amount of cash balance where there are profitable investment opportunities for them but they cannot do anything because the lack of cash available is compounded by the difficulty of obtaining external capital to finance the investment. It is unfortunate if there is a profitable investment opportunity to be neglected simply because of limited funds to finance it. It can be detrimental to the company itself as well as shareholders because the return that should have been obtained becomes less. Economic shocks that could hit the economy of a country at any time are also a threat of bankruptcy for companies that have small amounts of cash and limited access to external capital.

\section{The Tax Motive}

This motive explains the company's intention in determining the level of cash balances it has because the company prefers to hold cash to avoid the imposition of additional taxes that are perceived to be detrimental to the company, such as the imposition of tax on profits obtained from operating activities abroad and tax on dividend payments.

\section{The Agency Motive}

The motive for holding cash is also influenced by agency motives. The agent referred to here is the managers as the party who gets the authority from the shareholders to manage the company's assets in order to provide benefits to the shareholders.

Jensen (1986) says that managers try to hold back cash owned by the company rather than having to pay it to shareholders when the company has a small investment opportunity. These managers tend to use unemployed cash to benefit themselves. Whereas according to Ferreira and Vilela (2004), the benefits of cash holding include:

a. Reducing the possibility of financial difficulties (Financial distress).

b. Allows investment policies to be carried out when financial constraints occur.

c. Minimize costs to obtain funds externally or liquidate assets.

According to Opler et al. (1999) companies with strong growth opportunities, higher business risks, smaller size companies hold more cash than other companies. However, companies that have easy access to the capital market tend to hold less cash.

\section{Hypothesis Development Cash holding}

Cash holding is a ratio that compares the amount of cash and cash equivalents the company has with the total assets of the company (Baños-Caballero, García-Teruel, \& Martínez-Solano, 2010). Cash has the lowest profit rate compared to when cash is invested in other assets that are more profitable. Therefore, the availability of an optimal amount of cash for the company can affect the profits obtained by the company. If the amount of cash is too much, 
it will have an impact on the profits the company can get on every missed investment opportunity. But if too little the amount will also affect the company's liquidity. With sufficient cash available, companies do not have to sacrifice their investment opportunities to maintain their liquidity (Prasetianto, 2017). According to Hallegatte, Shah, Lempert, Brown, and Gill (2012) cash holding is defined as cash in the company or available for investment in physical assets and for distribution to investors. Companies are expected to have an optimal cash balance, namely cash balances that can maintain the company's liquidity, but also can maintain the company's productivity. The amount of cash is measured by the formula:

Detention of cash $=($ cash and cash equivalents $) /($ total assets)

\section{Liquidity}

Liquidity is the company's ability to fulfill short-term obligations. According to (Al-Najjar \& Clark, 2017), company liquidity is expected to reduce the cost of converting liquid assets into cash that is much lower than other assets. Liquidity can be measured by the formula:

Current Ratio (CR) $=$ (current assets) $/$ (current liabilities)

This current ratio measures the company's ability to pay current debt using current assets. The greater the ratio means the more liquid the company is. Companies with more liquid assets on the balance sheet than cash and securities also affect optimal cash holdings because these assets are considered as alternatives to cash. The cost of converting current assets to cash is very low compared to other assets, so companies with more liquid assets are expected to have a lower level of cash storage (Hunjra et al., 2012). The results of the research by Ferreira and Vilela (2004) show that if a company faces a lack of money, liquid assets can easily be used instead of cash. Opler et al. (1999) say that produce research that liquidity has negative effect on cash storage.

H1: Liquidity has a negative effect on cash holding.

\section{Leverage}

Leverage arises because the company in its operations uses assets and sources of funds that cause a fixed burden. Leverage shows the proportion of funding companies financed by debt. The higher the company's leverage means the higher the company's dependence on its creditors. This is consistent with agency theory, namely the agency relationship between the agent (creditor) and his agent (company). The company will try to provide as much information as possible about the condition of the company to its creditors. The hope is that creditors know and understand the companies related to credit. Leverage is divided into operating leverage and financial leverage. In operating leverage, the use of assets creates a fixed burden but in financial leverage, the use of funds creates a fixed burden. The leverage ratio used in this study refers to previous research. Debt to Asset Ratio (DAR) = (total debt $) /($ total assets) States that the more companies involved in large debt, the more companies increase the level of holding cash in anticipation of bankruptcy (Hallegatte et al., 2012). Negative influences can be explained by the argument of (Baños-Caballero et al., 2010) which states that corporate debt can be used instead of cash in investments so that large levers can save a small amount of cash. Debt as a substitute for cash means the higher the ratio of the company's debt, the lower the amount of cash held by the company. Leverage shows the ease of companies accessing debt. Leverage illustrates that companies that can access the debt market can use loans as a substitute for liquid assets. The relationship between debt and cash ownership is also explained in the pecking order theory. According to this theory, companies tend to use internal funding and less debt so that large cash holdings are held because debt is a cash substitution. The results of the research conducted by (Ozkan \& Ozkan, 2004) explain that the greater the leverage of the company, the company will experience a significant decrease in the amount of holding cash. Manuaba, Wiksuana, and Wiagustini (2014) explains that leverage shows the ease of the company in accessing funding sources in the capital market. If the company can easily get funding from debt, the company can save money in low amounts. Greater leverage shows the ease of the company in issuing debt. Corporate debt can be used to finance various investment opportunities for companies and is a substitute for cash for companies. The results of the study state that leverage has a negative effect, among others, Al-Najjar and Clark (2017) and Manuaba et al. (2014).

H2: Leverage has a negative effect on Cash Holding. Qi and Wang (2013) conducted a study of the factors that influence cash holding. Samples in the study were 465 companies from various countries from 1998 to 2003 in China. The dependent variable used is cash holding, while the independent variable, namely cash flows, growth opportunities, size, non-cash liquid assets and leverage. The results showed that cash flows, growth opportunities and size of firm had a positive effect on cash holding, while non-cash liquid assets and leverage had a negative effect on cash holding. Awunyo-Vitor and Badu (2012) conducted a study of the factors that influence cash holding. Samples in the study 
were 50 companies from 2012 to 2014 in Pakistan. The dependent variable used is cash holding, while the independent variables, namely debt structure, investment, board size, net working capital, leverage, firm size, profitability. The results of this study indicate that size, board size, net working capital and investment have a significant positive effect on cash holding, while the debt structure, leverage and profitability (ROA) have a not significant negative effect on cash holding.

From a number of studies regarding the cash holding described previously, it is still not specific to certain types of industries. While every industry can have a level of sensitivity to cash holding decisions such as industry banks and property industries. Banks must have sufficient capital, one of which can be supported by a cash holding. This is to avoid the risk of default and liquidity risk. Banks must have large amounts of cash holding. On the other hand, property is an industry that is not recommended to save too much holding cash. In accordance with the agency theory the problem that agency conflict can be reduced by is the reduction in cash holding. If too much cash holding is reserved, there is an indication of misuse of free cash flow. The nature of the property industry itself is to get a return on investment made so that the company will tend to minimize cash holding. This research focuses on the property industry because at present the demand for property in Indonesia is increas- ing along with the increasing population in Indonesia. Although research for cash holding is widely done, but for property industries it is still rarely done in Indonesia.

\section{RESEARCH METHODOLOGY}

The approach used in this study is a quantitative approach, because the data used are in the form of numbers and use statistical analysis. This research was conducted using a panel data regression model. This approach will focus on testing hypotheses, measuring the variables being studied, and generating generalized conclusions. Based on the problem formulation, hypothesis, and analysis model, the variables used for the analysis of this study are as follows: dependent variables in this study are cash holding, independent variables in this study are leverage and liquidity, and the control variables in this study are company size and dividend payment. Data used as research samples were obtained from the company's website in the 2012-2016 study period. Data collection is carried out through various procedures, namely preliminary research conducted by searching for and collecting various information and theories from literature, financial journals, and other materials related to the phenomenon of the problems discussed in the study. The analysis technique for processing data in this study uses a regression model with multiple linear analysis. With the regression model equation as follows:

$$
C A S H_{i t}=\alpha+\beta 1 C R_{i t}+\beta 2 D A R_{i t}+\beta 3 D P R_{i t}-\beta 4 S I Z E_{i t}+e
$$

\section{RESULTS}

In the variable description section, each variable is used in this study. Table 1 shows a description of variables that include minimum, maximum, average and standard deviation values. The dependent variable in this study is holding cash measured by the ratio of holding cash, while the indepen- dent variables used in this study include liquidity and leverage, while the control variables used in this study are dividend payments and company size. In Table 1, it can be seen that in property \& real estate companies, the average cash holdings of companies taken in 2012-2016 are 0.106, the lowest value is 0.004 and the highest value is 0.485 .

TABLE 1. Descriptive statistics

\begin{tabular}{llllll}
\hline \hline & N Minimum & Maximum & Mean & \multicolumn{2}{l}{ Std. Deviation } \\
\hline DAR & 175 & 0.034 & 0.740 & 0.376 & 0.165 \\
DPR & 175 & 0.000 & 0.849 & 0.089 & 0.129 \\
CR & 175 & 0.241 & 19.067 & 2.659 & 2.737 \\
SIZE & 175 & 16.537 & 24.543 & 21.629 & 1.689 \\
CASH & 175 & 0.004 & 0.485 & 0.106 & 0.092 \\
Valid N (listwise) & 175 & & & & \\
\hline \hline
\end{tabular}




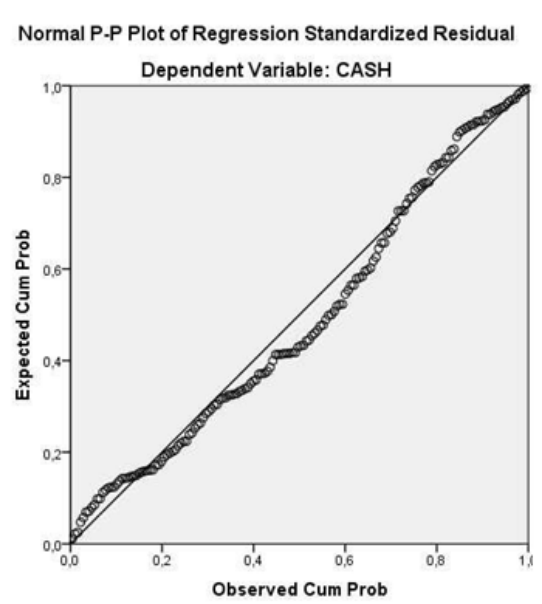

FIGURE 1. Statistic data test

Determination of a variable that is normally distributed or cannot be seen through a statistical test which includes histogram graph analysis, normal probability plots or Kolmogorov-Smirnov test. In this study using the Normal p-plot by visually viewing the distribution of points on the normal p-plot. If the points are still around the diagonal line, it can be said that the residuals spread normally. In property \& real estate companies the point on the normal p-plot is around the diagonal line and it can be said that the data is normally distributed.

The multicollinearity test aims to test whether there is a correlation between independent variables in a regression model. The model is considered to be free from the symptoms of multicollinarity if there is no independent variable that has a tolerance value of more than 0.1 and a VIF value of less than 10 . In the property \& real estate company the test results on the model show that the tolerance values of all independent variables are more than 0.1 and the VIF all independent variables are less than 10 which means that the regression model does not have multicollinearity.

The autocorrelation test was used to determine whether

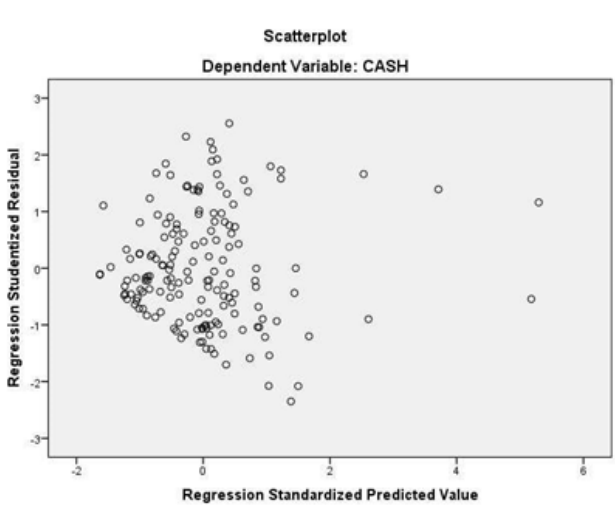

there was a relationship between observation errors in period $t$ with year $t-1$ errors. To detect the symptoms of autocorrelation, the Durbin-Watson test was used. The decision criteria in the Durbin Waston test, there was no autocorrelation if $-4<\mathrm{DW}<4$. The test results show that the property $\&$ real estate company shows 1.41 that there is no autocorrelation because the DW value is between -4 and $<4$.

The heteroscedasticity test aims to test whether the regression variance occurs in the residual inequality or other observations. The method used to detect the presence or absence of heteroscedasticity is to use a scatterplot graph. In the results of testing the regression model of the property \& real company, it shows that the graph plot spreads and does not form a regular pattern, meaning there is no heterocedasticity. Based on data variables that have been measured and tested using multiple linear regression models, the analysis was conducted to determine the effect of variable liquidity, leverage, dividend payments, and the size of the company holding cash in the property \& real estate sector. The results of the study can be seen in Table 2 .

TABLE 2. Results of analysis of the effects of CR, DAR, DPR, and SIZE on cash holdings of property and real

\begin{tabular}{llllll}
\multicolumn{7}{c}{ estate companies } \\
\hline \hline Model & \multicolumn{2}{l}{ Unstandardized Coefficients } & Standardized Coefficients & $\boldsymbol{t}$ & Sig. \\
\hline 1 (Constant) & .194 & .086 & & 2.257 & .025 \\
DAR & .032 & .043 & .057 & .732 & .465 \\
DPR & .047 & .052 & .066 & .902 & .368 \\
CR & .016 & .003 & .468 & 6.182 & .000 \\
SIZE & -.007 & .004 & -.123 & -1.694 & .092 \\
\hline \hline
\end{tabular}

a. Dependent Variable: CASH

Table 2 shows that liquidity has a significant positive effect on the cash holdings of property and real estate companies. Leverage does not have a significant positive effect on the cash holdings of property and real estate companies. Dividend payments do not have a significant positive effect on the cash holdings of property and real estate companies. 
Firm size has a significant negative effect on cash holdings of property and real estate companies.

\section{DISCUSSION}

The results of the regression analysis in Table 2 show that liquidity has a significant positive influence on the cash holdings of property and real estate companies. The results of this study contradict the hypothesis proposed because cash is part of the component of liquidity. When liquidity increases, cash holding will also increase. Al-Najjar and Clark (2017), Ozkan and Ozkan (2004) say that the more companies have liquid assets that are easily converted into cash without a significant change in value, the company does not need to hold large amounts of cash. Components of current assets in property companies are not as severe as other sectors, for example inventories in property and real estate companies in the form of buildings (hotels, cinemas, houses) which are generally illiquid and require a long time to be converted into cash. For this reason, the need for property and real estate companies to hold cash.

Property and real estate companies are companies with the majority of funding characteristics using bank loans. But the types of credit in the property sector and real estate funds can be withdrawn at any time by the public. If that happens suddenly, assets are classified as current assets of real estate companies, except cash and cash equivalents, even short-term credit sales receivables also depend on sales of inventory so that liquidity is unreliable. This positive influence is also caused because when a property company is able to fulfill its short-term obligations such as paying suppliers of building materials, the company must also hold cash to pay interest on bank loans and principal debt. Leverage does not have a significant positive effect on the cash holdings of property and real estate companies. This is because property and real estate companies hold large amounts of cash based on motives if there is a possibility of future or unexpected financial difficulties. Loans in the property and real estate sector are generally in the form of bank loans, while funds can be withdrawn at any time by a third party. If that happens, property companies must have weapons so they don't go bankrupt. In addition, the economic shock in 1997-1998 and 2008 affected the number of property and real estate companies that stopped abruptly. These changes many views about the importance of holding cash as the number of property and real estate companies increases depending on bank debt. Companies that have large leverage need to maintain cash liquidity, because banks as creditors analyze the level of company liquidity in lending. The results of this study are in line with Hallegatte et al. (2012) thinking, that the greater the company is involved in debt, the greater the need for cash to be maintained to avoid bankruptcy.

Dividend payments do not have a significant positive effect on the cash holdings of property and real estate companies. This means that companies that pay dividends to shareholders, holding cash will be bigger. This is consistent with the argument that companies need enough cash to pay dividends in the future and need to hold cash with a preventive motive. When the company has decided to pay a certain nominal amount, the company will experience a tendency to maintain payments within this range for the following years. The aim of the company to hold cash to pay dividends in the future is to create a good impression in the eyes of investors by providing stable dividends compared to providing large dividends and then providing a negative payment ratio in the following years. According to Banking and Trisakti (2016) arguments, companies have a lot of profit reserves that have been used both to be reinvested and distributed in dividends without having to change the proportion of dividends to shareholders, most of whom are managerial shareholders. The results of the study stating that dividend payments have a positive effect on holding cash include research by (Al-Najjar \& Clark, 2017) and (Banking \& Trisakti, 2016).

Firm size has a significant negative effect on cash holdings of property and real estate companies. This shows that the greater the property and real estate companies, the smaller the ownership cash made by the company. This is because small companies have a higher level of money storage than large companies because large companies are considered to have easier access to external funds and generally have a better image than small companies and diversification from large companies so they are less vulnerable to bankruptcy. Cost. In addition, smaller companies make it possible to liquidate their assets in the event of financial difficulties so they have more cash. Negative influence can also be explained that a larger company (described as a larger total asset as a ratio of dividers in holding cash) causes the ratio of holding cash to decline. The results of this study are in accordance with (Hallegatte et al., 2012).

\section{CONCLUSION}

The dilemma faced by companies is how many companies need to hold cash holding because cash is a non-learning asset while assets can be used for other investments that produce. The property industry has a high level of competitiveness and promising prospects going forward. The results of data analysis referring to research objectives, hypotheses, 
and analysis models, it can be concluded that in property and real estate companies, liquidity variables have a significant positive effect, variable size has a significant negative effect, and leverage and dividend payments do not have a significant positive against cash holdings. The more companies have liquid assets that are easily converted into cash without a significant change in value, the company does not need to hold large amounts of cash.

\section{IMPLICATIONS}

Property and real estate companies hold large amounts of cash based on motives if there is a possibility of future or unexpected financial difficulties. Loans in the property and real estate sector are generally in the form of bank loans, while funds can be withdrawn at any time by a third party. If that happens, property companies must have weapons so they don't go bankrupt. This research uses only one industry in one country. For the researchers, they can use adequate data and results in future.

\section{ACKNOWLEDGMENT}

The authors wish to thank Lembaga Pengelola Dana Pendidikan (LPDP) Scholarship for providing and supporting Authors to attend in Global Issues in Multidisciplinary Academic Research (GIMAR) 2019 in Japan.

\section{REFERENCES}

Al-Najjar, B., \& Clark, E. (2017). Corporate governance and cash holdings in MENA: Evidence from internal and external governance practices. Research in International Business and Finance, 39(7), 1-12. doi:https://doi.org/10.1016/ j.ibusrev.2012.02.004

Alshannag, F., Basah, M. Y. A., \& Khairi, K. F. (2017). The relationship between corporate social responsibility and corporate financial performance a survey of literature. International Journal of Business and Administrative Studies, 3(1), 9-15. doi:https://doi.org/10.20469/ijbas.3.10002-1

Antara, P. M., Musa, R., \& Hassan, F. (2016). Theorising attitude towards Islamic financing adoption in an integrative model of behavioural prediction: A proposed conceptual framework. Journal of Administrative and Business Studies, 1(1), 35-41. doi:https://doi.org/10.20474/jabs-1.1.6

Awunyo-Vitor, D., \& Badu, J. (2012). Capital structure and performance of listed banks in Ghana. Global Journal of Human Social Science, 12(5), 45-65.

Banking, I., \& Trisakti, U. (2016). Knowledge horizons-economics the determinants factor of islamic bank' s profitability and liquidity in Indonesia. Journal of Islamic Economics, Banking Finance, 8(2), 140-147.

Baños-Caballero, S., García-Teruel, P. J., \& Martínez-Solano, P. (2010). Working capital management in SMEs. Accounting and Finance, 50(3), 511-527. doi:https://doi.org/10.1111/j.1467-629x.2009.00331.x

Ferreira, M. A., \& Vilela, A. S. (2004). Why do firms hold cash? Evidence from EMU countries. European Financial Management, 10(2), 295-319. doi:https://doi.org/10.2139/ssrn.894865

Hallegatte, S., Shah, A., Lempert, R., Brown, C., \& Gill, S. (2012). Investment decision making under deep uncertaintyapplication to climate change. New York, NY: The World Bank.

Hosban, A. A. (2016). .accounting disclosure for stock goods and industrial companies IAS 2-An analytical study of industrial companies listed on the Amman Stock Exchange. International Journal of Business and Administrative Studies, 2(2), 24-28. doi:https://dx.doi.org/10.20469/ijbas.2.10001-2

Hunjra, A. I., Shabbir, G., \& Niazi, K. (2012). Real estate Indonesia dibidik investor asing. Retrieved from https://bit.ly/ 35X0NJk (Accessed on 16 July, 2018)

Jensen, M. C. (1986). Agency costs of free cash flow, corporate finance, and takeovers. The American Economic Review, 76(2), 323-329. doi:https://doi.org/10.2139/ssrn.99580

Jinkar Mali, S. (2011). Phytochemical and experimental study of latakaranja seeds [c. bonduc (l.) roxb] wsr to hepatoprotective activity (Unpublished master thesis). Univesity of Malaya, Kuala Lumpur, Malaysia.

Kompas. (2008). Artikel ini telah tayang di kompas.com dengan judul. Retrieved from https://bit.1y/2qv1Z6j (Accessed on 15 August, 2015)

Koroleva, I., Mierina, I., \& Karklina, I. (2017). Small rural schools on the edge of survival: Comparative assessment of stakeholders' perspectives in Latvia and Norway. Journal of Advances in Humanities and Social Sciences, 3(4), 214-225. doi:https://doi.org/10.20474/jahss-3.4.3 
Manuaba, I. B. P., Wiksuana, I., \& Wiagustini, N. L. P. (2014). Pengaruh pertumbuhan asset dan volume penjualan terhadap struktur modal dan penahanan kas. Buletin Studi Ekonomi, 19(2), 158-163.

Myers, S. C., \& Majluf, N. S. (1984). Corporate financing and investment decisions when firms have information that investors do not have. Journal of Financial Economics, 13(2), 187-221. doi:https://doi.org/10.3386/w1396

Opler, T., Pinkowitz, L., Stulz, R., \& Williamson, R. (1999). The determinants and implications of corporate cash holdings. Journal of Financial Economics, 52(1), 3-46. doi:https://doi.org/10.1016/s0304-405x(99)00003-3

Ozkan, A., \& Ozkan, N. (2004). Corporate cash holdings: An empirical investigation of UK companies. Journal of Banking and Finance, 28(9), 2103-2134. doi:https://doi.org/10.1016/j.jbankfin.2003.08.003

Prasetianto, A. (2017). Faktor keuangan dan non keuangan yang mempengaruhi kinerja pdam di Indoesia (Tech. Rep.). Universitas Sebelas Maret, Surakarta, Indonesia.

Qi, M., \& Wang, W. (2013). The monthly effects in Chinese gold market. International Journal of Economics and Finance, 5(10), 141-150. doi:https://doi.org/10.5539/ijef.v5n10140

Srisangkaew, K. (2017). Advanced destination marketing strategy for Chanthaburi Province, Thailand. International Journal of Business and Economic Affairs, 2(1), 77-84. doi:https://doi.org/10.24088/ijbea-2017-21010

Willy, S. (2017). Analysis of financial ratios to measure the company's performance in the sectors of consumer goods at Pt. Nippon Indosari Corpindo, Tbk and Pt. Mayora Indah, Tbk. International Journal of Business and Economic Affairs, 2(1), 45-51. doi:https://doi.org/10.24088/ijbea-2017-21006 